\title{
Main Principles and Practices of Auditing Independence in China:
}

\section{A Multifaceted Discussion}

\author{
Lan Wan Hua \\ Amsterdam Business School \\ University of Amsterdam, the Netherlands \\ E-mail: W.H.Lan@student.uva.nl
}

Georgios Georgakopoulos

Amsterdam Business School - Accounting Group

University of Amsterdam, the Netherlands

E-mail: g.georgakopoulos@uva.nl

Ioannis Sotiropoulos

Department of Finance and Auditing

Technological Educational Institute of Epirus, Greece

E-mail: sotiropoulosioan@yahoo.gr

Ekaterini Galanou

Department of Finance and Auditing

Technological Educational Institute of Epirus, Greece

E-mail: ketygalapatra@yahoo.gr

\begin{abstract}
This paper attempts through a review of the associated literature to describe and critically evaluate the audit market in China by exploring the main factors that affect auditor independence. The study identifies that non-audit service and low-balling/price-cutting are not parameters affecting auditor independence. Regulation can effectively help to maintain audit independence, but the enforcement of those regulations is very poor. Audit firm reputation is established and maintained by fulfilling the obligations of guanxi (personal relationship), rather than by reporting modified opinions fairly and trustfully. Due to government protection, competition in the Chinese audit market is limited and the possibility that Chinese audit firms lower their fees to retain clients is much diminished. Thus, competition and audit firm size appear to be positive aspects for audit independence. However, other national cultural and political-regulatory factors seem to have a moderating effect.
\end{abstract}

Keywords: Audit market, Audit independence, China, Competitiveness

JEL classification: M42, M41, D21

\section{Introduction}

Many foreign investors have entered the Chinese financial markets after the implementation of the country's open market policy some thirty years ago. As a result, the Chinese accountancy system expanded at a remarkable rate. The national government actively encourages foreign investors to participate in the domestic capital market and, as a result, the credibility of the auditing system has become of fundamental importance (Yang et al. 2003). In order to improve auditors' independence and to minimize the gap between the Chinese audit standards and the international audit standards, China is trying to keep in line with the International Accounting Standards. Under the guidelines of the latter, monitoring of auditors can effectively affect the behaviour of management; managers are less likely to manipulate earnings as meetings of audit committees are held more frequently (Xie et al. 2003). 
Successful implementation of the International Financial Reporting Standards in China, depends heavily on auditor independence. However, the environment in which auditing functions is still very different than that of western countries. Auditors in the country are perceived as non-independent to a large extent due to the relation between the state and the auditor associations (Yang et al. 2001). Additionally, the culture could be considered as an obstacle. Tsui (1996) has argued that the lower the level of ethical reasoning, the higher the likelihood that auditors would accede to clients' requests.

There are six widely discussed factors in academic literature affecting auditor independence (i.e. non-audit services, regulation, audit reputation, competition, low-balling, and size of audit firms). Non-audit service, competition and low-balling are regarded as the negative factors that could impair auditor independence (DeFond et al. 2002, Ashbaugh et al. 2003, Shockley 1981). Craswell (1999) argues that non-audit service does not impair auditor independence. De Angelo (1981a) claims that low-balling also does not impair auditor independence. Lee and $\mathrm{Gu}$ (1998) even suggest that low-balling could reduce the transaction costs associated with the audit engagement relative to the flat-fee structure and it could actually improve auditor independence. Regulations, reputation and audit firm size are, on the other hand, regarded as parameters that could improve auditor independence (Magee and Tseng 1990, Arrunada 2000, Wilson and Grimlund 1990, DeAngelo 1981b, DeFond et al. 2000).

The above elements have been examined widely in developed countries. However, in China research has focused mostly on the unique political, cultural and economic environment neglecting the previously mentioned factors affecting auditor independence. This paper attempts through a review of the associated literature to explore the significance of the latter if placed in the Chinese environment. As a result, we argue here that non-audit service is not a factor that could affect auditor independence since Chinese CPA firms are still at the stage of changing their focus from taxation audit services to financial statement audit. China has been trying to harmonize its audit standards with the international standards and to regulate the behaviour of auditors. However, there are problems enforcing those regulations; due to Chinese culture considerations reputation issues are conceptualised differently. Audit firm size also seems to be a positive factor for audit independence.

The paper will develop as follows: The next section provides a brief historical overview of the auditing system in China with a focus on the audit changes undertaken and the influence of the Chinese political-regulatory institutions on auditing. This is then followed by a comparison of the factors identified by the academic literature affecting audit independence with the Chinese reality. The paper concludes with a summary of our findings and our thoughts for future research in the area.

\section{Brief historical analysis of the auditing system in China}

In light of the global economy, China has performed a series of financial reforms. The latter are different from these undertaken in Eastern Europe that mainly copied and applied western-style market systems. The work undertaken in the country is more experimental and it has aimed at improving performance rather than thoroughly changing the financial system. China's reform path is more akin to grow out of the reform plan (Naughton 1994).

The Chinese Certified Public Accounting (CPA) profession was established in 1918. Four Chinese CPA firms were founded in the 1920s and until 1947 there were 3,356 registered practices in the country (Gensler and Yang 1996). However after the revolution of 1949 , the role of auditing in the national economy significantly changed. The socialist government established a single "publicly owned" economy, centralized business management, and controlled all economic resources. By 1956, the audit practice had been replaced by a system of specialist supervision and internal accounting control (Xiao et al. 2000). After the economy was nationalized in 1962, the audit function performed by public accountants was annulled (Gensler and Yang 1996).

In 1970 China followed the Soviet model. However, the implementation of this crude system failed to reflect and capture the complex nature of modern transactions and the contemporary business concept of the accounting system. A group of badly trained professionals performed the detailed recording of transactions. These professionals were the first accountants in the country with no related education and/or appropriate training (Graham 1996).

Till the early 1990s, the audit practice was still directed and regulated by the State. There are two organizations reporting separately to the Council of the State. One is the Ministry of Finance and the other one is the State Audit Administration (Winkle et al. 1994). The auditing system in China has, in very few occasions, served the purposes of financial position reporting. The system was employed instead to collect data that were used to monitor compliance with State aims and for tax purposes (Lau and Yang 1990). 


\subsection{Audit market reforms}

The numerous regulations introduced by the government with regards to the Chinese financial system require the involvement of independent auditors in order to implement the associated economic measures (Tang et al. 1992). As a result, the aim of the audit market reform is to develop an audit profession that will help the market work efficiently (Xiao et al. 2000). Due to a series of economic modifications in the early 1980s, foreign investment grew rapidly in China. Economic changes also stimulated the growth of the CPA profession (DeFond et al. 2000). Globalization of economic activities accelerated conformity to international accounting practice principles (Tang 2000).

The first stage in audit reforms started in the 1980s. Following economic advancement, foreign investors entered the Chinese market mostly in the form of joint ventures. The foreign enterprises had a different capital structure from the domestic (state-owned) ones. Thus, the 1985 Regulation was established with the purpose to harmonize the Chinese reality with the international practice by formulating financial reporting (Chow et al. 1995).

The second phase began in the early 1990s. After the establishment of the Shanghai Stock Exchanges (SSE) and Shenzhen Stock Exchanges (SZSE), China completely changed its accounting system. There have been two main types of shares in the national capital market since then; an A-share and a B-share. A-shares were only allowed to be issued to domestic investors. In 1992, some listed companies were also authorized to issue B-shares to foreign investors (Chui 1998, Chen et al. 2001). In response to these changes in the stock market, the national government issued the Accounting Regulation for Experimental Listed Companies in 1992 (Chen et al. 2002). To improve auditor independence, the Chinese government adopted three sets of auditing standards in 1995, 1997 and 1999 respectively. These standards were patterned after the International Auditing Standards (IAS).

The most significant change in the third stage is that fund-orientated accounting practices are annulled and industry-based accounting regulations are established as a conceptual framework. The issuing of the first accounting standard: "Accounting Standard for Enterprises" altered the traditional function of accounting from gathering data for State decisions to focusing on the needs of external users of financial information (Yang 1994).

\subsection{Complications in auditing environment}

The successful implementation of the financial reforms introduced in the country since the 1980s (a more market-driven economy, aligning of national accounting rules with international practices, improvement of auditing standards) depends on the principle of Guo Qing. The latter notion implies that any change will be implemented only in conjunction with the Chinese needs (Graham and Li 1997) and any inherent limitations of the cultural and political system these carry.

Chinese have a strong sense of group belonging. Conflict resolution in this context requires self-sacrifice for the interest of the whole group. To maintain harmony people are asked to behave in a manner appropriate to their position. This feature could explain to a certain extent the tendency of a more secretarial way of information disclosure (Hofstede 1991). What connects people in a group is the notion of guanxi. In the Chinese language this signifies the existence of a personal relationship. It refers to the network(s) of existing informal relationships and favours' exchange that dominate all businesses and social activities throughout the country (Lovett et al. 1999).

The conduct of business is based on trust. So, business people will first build personal relationships with potential customers. Trust can also be established through the formation of groups. Thus, business will normally follow the formation of a group (Hwang and Staley 2005). As soon as trust is established, bad debt expense(s) and related allowances will be lowered. This is because guanxi creates obligations to conduct business within the formed group and obligations to pay back associated debts. Group members will try to meet their guanxi responsibilities. If they fail then a loss of prestige and trust will follow. In this context the establishment, development and maintenance of the guanxi code are a fundamental priority of many business people in the country (Hwang and Baker 2000). In line with this, Yeung and Tung (1996) argue that guanxi is the most critical factor driving business success in China (see also Hwang and Staley 2005). Most business and credit arrangements undertaken are related to the guanxi code than to a company's financial position (Graham 1996). For this reason local and state-owned enterprises hire smaller local auditors than non-state firms (Wang et al. 2008).

Guanxi could be a major impediment for auditor independence. This is complemented however by auditor unethical behaviour and a misunderstanding of their role by auditees. In relation to the former, audit unethical 
behaviour can result from a focus on the profit and loss account rather than on audit quality (Xiao et al. 2000). On the other hand, auditees sometimes do not understand audit work. The cost from receiving a modified report is high, while the benefit from receiving a modified report is low. Heading to this direction managers would prefer smaller, less independent auditors, and avoid larger, more independent ones (DeFond et al. 2000) since the former could accept to put together slightly modified reports to attract more clients. Auditees also expect auditors to help them conceal frauds (illegal spending, tax evasion) or cover weaknesses of their businesses (Yang 1995).

In general, the rapid increase of the auditing firms was accompanied by audit quality problems underlined by a lack of an indication of the auditing standards used, vague descriptions of the scope of the audit, and misleading audit opinions. In order to tackle this, the Chinese government adopted a new set of auditing standards in 1995. The new standards introduced detailed auditing procedures and penalties for violating auditing standards (DeFond et al. 2000).

\subsubsection{Political-regulatory limitations}

The traditional class system emphasised obedience to the superior and the ruler. Confucianism strengthened these views by incorporating them within the family arrangements (Cheng 1980) making these class relationships the bases of the Chinese society (Hofstede 1991). As a result, the latter became bureaucratic with a highly structured centralised administrative system (Berry 1988) and large societal power-distance (Hofstede 1984). Power distance refers to the extent to which the members of a society accept unequal distribution of power in their institutions and organizations. These societal settings prefer to place emphasis on government involvement, rather than reliance on independent professionalism (Chow et al. 1995).

Before the 1980 reforms the government centrally planned and managed the national economy. A significant development then was to separate the ownership from the management of enterprises. In this context, even though the state maintained ownership of most enterprises, people were given more and more autonomy to make business decisions. After this development, the dominant form of enterprising changed to business contracting. This materialised to stimulate contractors (managers and employees of the associated companies) to improve the efficiency of the state-owned companies (Chen et al. 1997). The subsequent 1995 economic reform focused on the state-owned enterprises themselves. All small state-owned companies making losses, with high liabilities, using obsolete technology were closed down. Medium and large business contracting enterprises started to issue share capital (Yang 1995) with the state maintaining most of the ownership of the issued stock (Xu and Wang 1999).

\subsubsection{Contemporary Chinese context for the audit firms}

There are three types of shares that a listed company can issue: shares that can be owned only by the state directly; shares that can be owned by state institutions; and shares issued to individual investors. Stock held by the state cannot be traded. There is limited trading allowed for stock held by state-institutional investors in designated markets. Only shares held by individual investors can be traded freely in the stock exchange (DeFond et al. 2000).

State-owned enterprises enjoy some special treatment in the capital market; the government for example allows local and centrally owned state enterprises to report three years of pre-IPO estimated earnings (Wang et al. 2008). However this condition incentivises governmental entities to manage their earnings and, as a result, they do not require independent auditors (DeFond et al. 2000).

In the US, IPO firms tend to hire larger auditors signalling thus the capital markets about their value and transparency (Beatty 1989). In contrast, in China since most of these firms are controlled by governmental entities when listed, the investors are certain for their success and future business as these are guaranteed by the state (DeFond et al. 2000). The Chinese government will provide bailout in order to avoid civil unrest that could be caused by worker layoffs (Wang et al. 2008). As a result, the investors seldom pay attention to the qualification and degree of independence of the chosen auditors (DeFond et al. 2000). In addition, the traditional relationship between the state and the Chinese auditor associations has remained a major problem (Xiao et al. 2000) still resulting to a lack of auditor independence (Yang et al. 2001). It is indicative that $75 \%$ of the audit clients are government affiliated firms. The overwhelming controlling power of the state in both clients and their auditors gives little incentive for the companies to acquire independent auditors and for the auditors to behave independently (Yang et al. 2003).

In order to accelerate auditor independence a disaffiliation program was carried out at the end of 1996. During 1997, the auditor firms were gradually separated from government and by the end of 1998 nearly all audit firms 
had become independent. Nowadays CPAs have more autonomy. They can form their own business strategies and policies while at the same time they bear all the business risks of their new position(s) (Yang et al. 2001).

However, indirect state control remains since the state is still the dominant shareholder in most listed and unlisted companies. Local governments have the statutory power to ask state-owned enterprises not to employ auditors (Wang et al. 2008). The local government can also exercise its influence on audit firms through its finance and audit bureaus since licensing of audit firms has to go through the local CPA institutes. The administration of professional accreditation exams takes place in these, while day-to-day operations of audit firms are also regulated by the local CPA institutes (Tang 1999). In addition, many of the local audit firms' partners are ex-bureaucrats of the local governments. The people working for the governmental entities and the auditors working for the disaffiliated CPA firms have remained the same. As a result, the sponsoring agencies and auditors maintain close relationships in pursuing their own interests (Gul et al. 2009).

All the above factors could well render the disaffiliation program ineffective in improving auditor independence, or could even reduce auditor independence in practice.

\section{Factors affecting audit independence - a comparison with the Chinese reality}

\subsection{Non-audit services}

A business in order to succeed in the competitive environment of the capital markets is often offered financial consultation (non-audit services) by audit firms. Non-audit services could save costs and add value for the clients (William and Kinney 2005); at the same time a conflict of interest often arises between maintaining high quality audits and preserving the consulting contracts. In order to regulate the auditors' behaviour, there is a series of regulations and standards, which in most cases, can be effective. Failure to comply with those would result to litigation and reputation loss. The bigger the audit firm is, the more attention it draws from government and regulators resulting in increased risks in case of non-compliance than smaller companies. This could be circumvented through the practice of low bailing. Namely audit firms in their effort to satisfy clients' requirements and avoid interference in their practice (and as a result report less modified opinions), reduce their audit price. However, larger audit firms, only earn client-specific quasi-rents through non-audit service provision and have a disincentive to give up their independence in order to retain specific clients.

After the implementation of the 1980 open financial policy, the Big 4 audit practices entered the Chinese capital markets. In 1993, with the deepening of the economic reforms, foreign companies were allowed to form joint ventures with the Chinese state-owned companies. Although nowadays the state-owned enterprises are still the dominant forms of the Chinese economy, the economic changes allow for more enterprise types to co-exist with state-owned ones, (e.g. collective enterprises, private enterprises, foreign investment ventures). China has been oriented towards a private ownership model. In this context the separate role of ownership and management required independent audits and as a result the traditional function of auditing for assessing tax compliance has gradually changed towards qualified opinion provision on financial statements. However, given this recent change in the mentality of the system Chinese CPA firms do not provide substantial non-audit services (Yang et al. 2001) yet. Therefore, there are fewer incentives to give up their independence comparing with the practices in the US, Europe, and elsewhere.

\subsection{Regulations}

Statutory penalties for non-compliance with audit standards can be severe in China. Auditors could have their practice licences revoked or even face imprisonment (DeFond 2000). Since changes in firm structure and legal form, auditors have significantly increased their audit risk levels. The number of litigation cases and administrative sanctions against practices increased significantly between 1994 and 1998 (DeFond 2000).

Academic research indicates that auditor firms in countries with strong incentives to protect investors and high quality judicial systems are more likely to report bad news about qualified reports than those with weaker protections and judicial systems in place (Bushman and Piotroski 2006). Allen et al. (2005) have tested the degree of investor protection in China. They argue that levels of law enforcement are below all average measures of other sample countries due to the rule of law and corruption. Many new laws are not enforced effectively because of the intrinsic conflict of interest between fair practice of law and the monopolising power of the one and only ruling political party. Due to the still close links between the government and the audit practices and the adherence to the guanxi code of conduct especially in cases in which government officials or their affiliates are involved, law enforcement can be problematic. According to this reasoning, the country is regarded as one of the worst in investor protection (Brockman and Chung 2003). 
Comparing to countries with lower state involvement in the national economy, in countries with high state attachment, firms speed up recognition of good news and delay recognition of bad news in reported earnings (in contrast to the conservatism principle in revenue realisation). Managers thus appear to adjust their financial position in response to the nature of the State's involvement (Bushman and Piotroski 2006). Force of politics seems to be over and above regulatory powers making the former a stumbling stone in the way of auditor independence.

\subsection{Reputation}

Investment decisions of financiers depend heavily on qualified audit opinions. Thus, quality of auditors is important but the investors don't know how to judge that and they consider auditor's reputation and brand name as an indicator of that quality. High quality of the audit is presumed as an assurance that the financial reports are made independently. When investors have trust in auditors, they also trust the companies whose financial statements were/are checked. DeFond et al. (2000) argue that the new Chinese auditing standards have improved auditors' independence since the 1995 disaffiliation programme from the government. However this does not convey the complete story. Auditor reputation in the country also depends on their guanxi relationships as discussed previously, and as a result, the former as derived from the guanxi code of conduct (with its affiliated drawbacks) is much more important and predominant than being reputed as a good audit practice.

\subsection{Competition}

The disaffiliation program of the audit practices was an important step to break market protectionism in audit and accounting. By the end of 1997, foreign accounting firms had acquired nearly 10 percent of the Chinese auditing market with this participation to be growing (Yang et al. 2003). Many foreign audit firms also entered the country in the form of joint venture and associate formations with local CPAs. These firms audit the financial statements of Chinese companies issuing stock to foreign investors ("B" shares).

In the light of even this limited market auditors compete and in theory they could use unethical measures to retain or increase their client base (i.e. accepting client intervention to report modified opinions). However before audit practices can audit foreign owned, joint venture companies or Chinese stock companies listed on the exchange, they have to be approved and authorised by the State (Graham 1996). Furthermore, these overseas firms are not allowed to audit most of the unlisted companies and state-owned enterprises. All these restrictions are in place to protect and develop the local audit practices since otherwise Chinese CPAs might not be able to survive the competition with the large multinational audit firms. In this context, competition cannot become a main reason for Chinese auditors to abandon or reduce independence to retain clients.

\subsection{Low-balling and price-cutting}

In the light of the relatively reduced competition among audit practices in the country, low bailing is not a factor that can affect audit independence. Retaining clients by lowering audit price is not prevalent in the national audit market. Additionally, Wang et al. (2009) report that the Big 4 earn an audit premium in the country. They can charge a higher audit fee than the local practices because of their name and reputation. This lack of brand name and reputation prevents Chinese CPAs from gaining an additional market share by applying low-balling practices.

\subsection{Audit firms size}

Lia et al. (2004) have examined the association between audit firm size and audit quality in China. They report that the big audit firms can better resist client pressure than smaller practices and they are less likely to issue modified opinions. So practice size seems to matter in maintaining audit independence in the national capital markets

\section{Conclusion}

Few Chinese CPA firms offer non-audit services. This however, does not appear to be a cause that affects auditors' independence, and the audit firm size is indeed a positive factor that helps audit practices to maintain independence. The Chinese special political and cultural environment could be of concern to investors. Nonetheless, this does not necessarily carry negative effects. Due to state protectionism, the competition in the Chinese audit market is limited, and low bailing opportunities are much reduced. In an attempt to enhance its capital market, China has been trying to keep its audit standards in line with the international ones and regulate auditor behaviour. However there are issues with regulation enforcement due to aspects of political power. In the past 30 years, the Chinese government has showed its determination to change its investing environment step by step. Culture can be regarded as another obstacle in the way of improving audit independence. The reputation aspects are defined and dealt with through the guanxi (personal relationship) code of conduct, rather than by 
reporting modified opinions fairly and trustfully. To avoid guanxi from undermining auditor independence and audit quality, Hwang and Staley (2005) suggest ensuring the public interest with high levels of ethical principles and practices in the audit firms. In this context, China has issued the General Standard on Quality Control to ensure that all audits are conducted in accordance with relevant laws and regulations.

There are limitations in our work. Due to length considerations only some factors affecting audit independence deemed as important for the Chinese context are discussed here and no actual fieldwork was undertaken. The academic literature has mostly emphasised the negative impact of political and cultural influences in the country and factors that affect audit independence only in the developed segment of the audit market. Future research could expand in the developing segment of the market as well. Under the national political and cultural conditions the influence of some of the factors on audit independence discussed by the international academic literature is limited. It is not possible to remove the political and cultural effects but by observing the efforts the Chinese government has made, the political power could be used to strengthen audit independence more effectively. Further research (quantitative or qualitative) could examine how the strengthening and enforcement of audit regulations as well as a weakening of the cultural influences can be made possible.

\section{References}

Allen F., Qian J and Qian M. (2005). Law, Finance and Economic Growth in China. Journal of Financial Economics, 77(1): 57 - 116 .

Arrunada B. (2000). Audit quality: Attributes, Private Safeguards and the Role of Regulation. European Accounting Review, 9(2): 205 - 224.

Ashbaugh H., LaFond R. and Mayhew B.W. (2003). Do Audit Services Compromise Auditor Independence? Further Evidence. The Accounting Review, 78(3), 611 - 639.

Beatty R. (1989). Auditor Reputation and the Pricing of Initial Public Offerings. The Accounting Review, 64: 693 $-709$.

Berry M. (1988). The Cultural Development of Accounting in the People's Republic of China. Recent Accounting and Economic Development in the Far East. Centre for International Education and Research in Accounting.

Brockman P. and Chung D.Y. (2003). Investor protection and Firm Liquidity. The Journal of Finance, 8(2): 921 $-937$.

Bushman R.M. and Piotroski J.D. (2006). Financial Reporting Incentives for Conservative Accounting: the Influence of legal and Political Institutions. Journal of Accounting and Economics, 42: 107 - 148.

Chan H.K. and Lin K.Z. (2000). Auditing Standards in China. A Comparative Analysis with Relevant International Standards and Guidelines. The International Journal of Accounting, 35(4): 559 - 577.

Chen S.M., Chen S.M. and Su X.J. (2001). Is Accounting Information Value-Relevant in the Emerging Chinese Stock Market? Journal of International Accounting, Auditing \& Taxation 10: 1 - 22.

Chen S.M., Sun Z., Wang Y.T. (2002). Evidence from China on Whether Harmonized, Accounting Standards Harmonize Accounting Practices. Accounting Horizons, 16(3): 183 - 197.

Chen Y., Jubb p. and Tran A. (1997). Problems of Accounting Reform in the People's Republic of China. The International Journal of Accounting, 32(2): 139 - 153.

Cheng T.K. (1980). The World of the Chinese. A struggle for Human Unity. The Chinese University Press.

Chow M.Y., Chau K.K., Gray S.J. (1995). Accounting Reforms in China: Cultural Constraints on Implementation and Development. Accounting and Business Research, 26(1): 29 - 49.

Chui C.W. (1998). Cross-Autocorrelation between A-Shares and B-Shares in the Chinese Stock Market. The journal of Financial Research, 21(3): 333 - 353.

Craswell A.T. (1999). Does the Provision of Non-Audit Services Impair Auditor Independence? International Journal of Auditing, 3(1): 29 - 40.

DeAngelo L. E. (1981a). Auditor independence, "Low Balling," and Disclosure Regulation. Journal of Accounting and Economics, 3(2): 113 - 127.

DeAngelo L. E. (1981b). Auditor Size and Audit Quality. Journal of Accounting and Economics, 3: 183 - 199.

DeFond M. L., Wong T.J., Li S.H. (2000). The Impact of Improved Auditor Independence on Auditor Market Concentration in China. Journal of Accounting and Economics, 28: 269 - 305. 
DeFond M.L., Raghunandan K. and Subramanyam K.R. (2002). Do Non-Audit Service Fees Impair Auditor Independence? Evidence from Going Concern Audit Opinions. Journal of Accounting Research, 40(4): 1248 1274.

Gensler H. and, Yang J. (1996). Auditing Standards of the People's Republic of China. FT Law \& Tax Asia Pacific. Hong Kong.

Graham L.E. (1996). Setting a Research Agenda for Auditing Issues in the People's Republic of China. The International Journal of Accounting, 31(1): 19 - 37.

Graham L.E., Li C.Y. (1997). Cultural and Economic Influence on Current Accounting Standards in the People's Republic of China. The International Journal of Accounting, 32(3): 247 - 278.

Gul F.A., Sami H and Zhou H.Y. (2009). Auditor Disaffiliation Program in China and Auditor Independence. Auditing: a Journal of Practice \& Theory, 28(1): 29 - 51.

Hofstede G. (1984). Cultural Dimensions in Management and Planning. Asia Pacific Journal of Management, 1(2): $81-99$.

Hofstede G. (1991). Cultures and Organizations Software of the Mind. MCGraw Hill.

Hwang D. B. K. and Baker. R. L. (2000). Proceedings of Global Awareness Society. International Conference, New York, $71-76$.

Hwang D. B. K. and Staley A. B. (2005). An Analysis of Recent Accounting and Auditing Failures in the United States on US and Auditing in China. Accounting Managerial Auditing Journal, 20(3): 227 - 234.

Lau A. H., Yang J. (1990). Auditing in China: Historical Perspective and Current Development. International Journal of Accounting, Education and Research, 25: 53 - 62.

Lee C. J. and Gu Z. Y. (1998). Low Balling, Legal Liability and Auditor Independence. The Accounting Review, 73(4): $533-555$.

Lia C., Songa M. F. and Wongb S. (2004). Audit Firm Size Effects in China's Emerging Audit Markets. University of Hong Kong working paper.

Lovett S., Simmons L.C. and Kali R. (1999). Guanxi Versus the Market: Ethics and Efficiency. Journal of International Business Studies, 30(2): 231 - 247.

Magee R. P. and Tseng M. C. (1990). Audit Pricing and Independence. The Accounting Review, 65(2): 315 336.

Naughton B. (1994). Growing Out of the Plan: Chinese Economic Reform, 1978-1993. New York: Cambridge University Press.

Shockley R. A. (1981). Perceptions of Auditors' Independence: an Empirical Analysis. The Accounting Review, 56(4): $785-800$.

Tang Y. W., Cooper B. J., Chow L. (1992). Accounting and Finance in China, A review of Current Practice. Hong Kong: Longman.

Tang Y.W. (1999). Issues in the Development of the Accounting Profession in China. China Accounting and Finance Review, 1:21-36.

Tang Y.W. (2000). Bumpy Road Leading to Internationalization: A Review of Accounting Development in China. Accounting Horizons, 14(1): 93 - 102.

Tsui J. S. L. (1996). Auditors' Ethical Reasoning: Some Audit Conflict and Cross Cultural Evidence. The International Journal of Accounting, 31(1): 121 - 133.

Wang Q., Wong T. J. and Xia L. J. (2008). State Ownership, the Institutional Environment and Auditor Choice: Evidence from China. Journal of Accounting and Economics, 46(1): 112 - 134.

William R. and Kinney J. (2005). Twenty-five Years of Audit Deregulation and Re-Regulation: What does it Mean for 2005 and Beyon. A Journal of Practice and Theory, 24: 89 - 109.

Wilson T. and Grimlund W. (1990). An Examination of the Importance of an Auditor's Reputation. A Journal of Practice and Theory, (9): 43 - 59.

Winkle G. M., Huss H. F., Chen X.Z. (1994). Accounting Standards in the People's Republic of China: An Update. Accounting Horizons, 8(3): 48 - 57. 
Xiao Z.Z., Zhang Y.K., Xie Z.H. (2000). The Making of Independent Auditing Standards in China. Accounting Horizons, 14(1): $69-89$.

Xie B, Davidson W. N., Dadalt P. J. (2003). Earnings Management and Corporate Governance: the Role of the Board and the Audit Committee. Journal of Corporate Finance 9: 295 - 316.

Xu X.N., Wang Y. (1999). Ownership Structure and Corporate Governance in Chinese Stock Companies. China Economic Review, 10: 75 - 98.

Yang J.W. (1994). Moving Towards Accounting Internationalisation. The Proceedings of the Sixth Annual Conference of Accounting Academics. Hong Kong Society of Accountants.

Yang L., Dunk A., Kilgore A., Tang Q.L., Lin Z.J. (2003). Auditor Independence Issues In China. Managerial Finance, 29(12): $57-62$.

Yang Q. (1995). Four Ways to Reform State-Owned Enterprises. Hebei Finance and Accounting, 27.

Yang, L, Tang, Q., Kilgore, A., and Jiang, Y. ( 2001). Auditor-Government Association and Auditor Independence in China. British Accounting Review, 33(2): 175 - 189.

Yeung, I.Y.M. and Tung, R.L. (1996). Achieving Business Success in Confucian societies: the Importance of Guanxi (Connections). Organizational Dynamics, 25(2): 54 - 65. 